INSIGHTS INTO REGIONAL DEVELOPMENT

ISSN 2669-0195 (online) http://jssidoi.org/IRD/

2019 Volume 1 Number 2 (June)

http://doi.org/10.9770/IRD.2019.1.2(6)

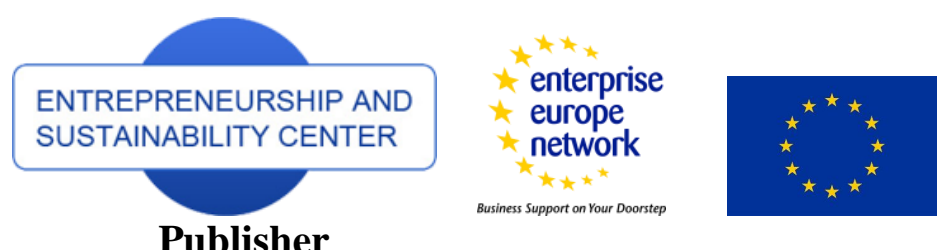

http://jssidoi.org/esc/home

\title{
USING THE CAPABILITY APPROACH AND ORGANIZATIONAL CLIMATE TO STUDY OCCUPATIONAL HEALTH AND SAFETY*
}

\author{
Andrea Bernardi \\ Oxford Brookes University, Gipsy Lane Oxford, OX3 OBP, United Kingdom \\ E-mails: abernardi@brookes.ac.uk
}

Received 16 March 2019; accepted 28 May 2019; published 30 June 2019

\begin{abstract}
The Capability Approach, first developed by Amartya Sen, cab be used as a mean to analyse occupational health and safety related behaviours. Accidents at work more frequently occur among atypical workers and migrants, making this an interesting context in which to apply Sen's theoretical framework; namely showing how freedoms, rights, organisational climate and capabilities are important factors in risk prevention. It is logical to expect that workers' participation and rights should provide a safer environment, but the application of the Capability Approach offers a tool to measure organisational inequalities and their consequences. Furthermore, its application could help to improve occupational health and safety chiefly among atypical workers. In this paper, I consider Safety Capability to encompass the workers attitude to their own protection, their understanding of safety procedures and the risks they face, and their freedom to ask their organisation to comply with the law and implement safe work processes.
\end{abstract}

Keywords: capability; health and safety; organizational climate; organization; wellbeing

Reference to this paper should be made as follows: Bernardi, A. 2019. The capability approach and organizational climate as tools to study occupational health and safety, Insights into Regional Development 1(2): 155-170. https://doi.org/10.9770/ird.2019.1.2(6)

JEL Classifications: J28, O15, D23

Additional disciplines: law; political sciences; sociology; psychology

* Parts of this text are spinoffs from research in the framework of the project European Union's Horizon 2020 Research and Innovation Programme projects European Cohort Development Project (ECDP) Grant Agreement No.777449 (2018-2019)

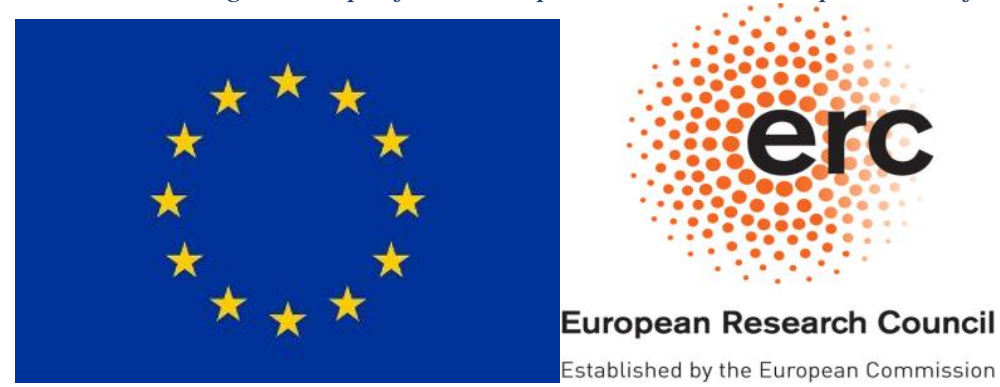




\section{Introduction}

This paper, after a brief statistical analysis of occupational safety trends, summarises different research perspectives on occupational well-being and safety. There is no doubt from the statistics that higher incidences of accidents and fatal accidents occur among non-standard workers than among standard workers. Occupational Health and Safety (OHS) is a key organisational priority to reduce risk and promote employees' well-being.

As well as applying Amartya Sen's Capability Approach to OHS behaviours, this paper's contribution lies in the way it introduces and discusses the role of organisational climate as an important mediator linking workers' contractual status (standard/non-standard, permanent/atypical) with their attitudes and behaviour in relation to safety. As such, this paper proposes a new theoretical methodology to deal with OHS issues, and further suggests cross-border co-operation among social sciences in this field. According to Eurofound: Atypical work refers to employment relationships not conforming to the standard or 'typical' model of full-time, regular, open-ended employment with a single employer over a long-time span. 'Typical' work in contrast is defined as a socially secure, full-time job of unlimited duration, with standard working hours guaranteeing a regular income and, via social security systems geared towards wage earners, securing pension payments and protection against ill-health and unemployment.

The motivation for carrying out this research lies in the official statistics on labour safety, although these in themselves present considerable difficulties. Any comparison between European countries becomes immediately methodologically difficult, especially when dealing with all 27 member states. At best, standard indexes and harmonized figures therefore have to be used (Figure 1). Germany and the UK outperform Italy that in turn outperforms France in terms of their OHS.

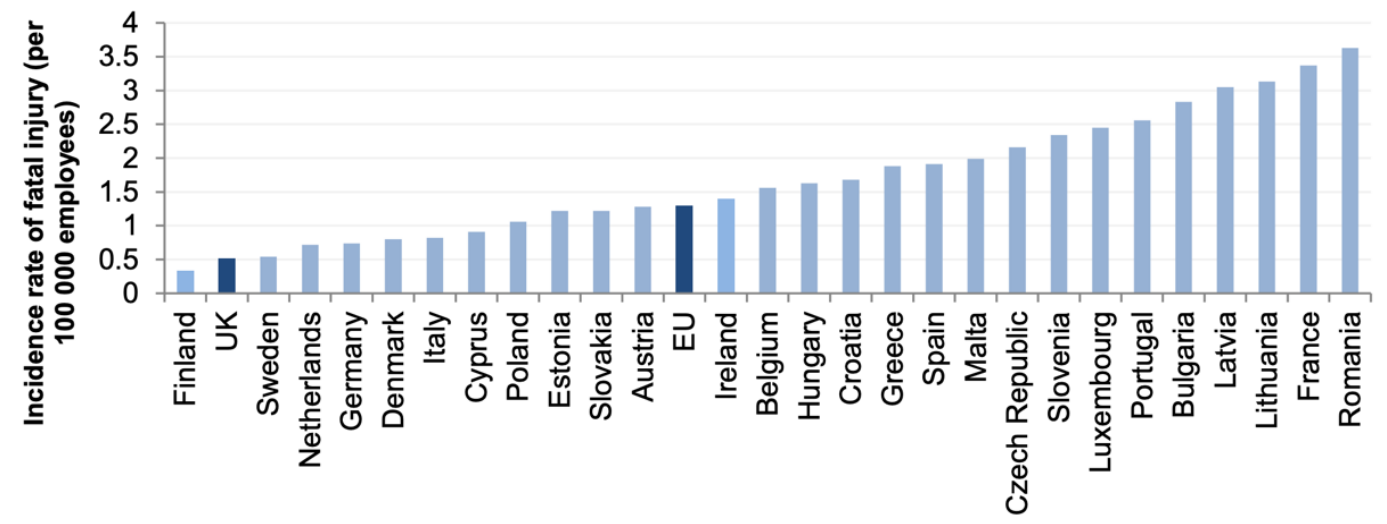

Fig. 1. Standardised incidence rates (per 100,000 employees) of fatal injury at work, excluding road traffic accidents for 2015. Source: Eurostat, ESAW, 2015.

An index of disabilities and fatal accidents occurring at work in Britain, organised by industry (Figure 2) reveals some industries being unsurprisingly safer than others. Equally unsurprising, is finding that the most "dangerous" industries are named as being those associated with agriculture, fishing and forestry. Other features are less predictable, however. Construction performs better than public administration and human health. Such findings 
INSIGHTS INTO REGIONAL DEVELOPMENT

ISSN 2669-0195 (online) http://jssidoi.org/jesi/

2019 Volume 1 Number 2 (June)

http://doi.org/10.9770/IRD.2019.1.2(6)

strongly suggest that technology is not the only variable needed to explain risk. Safety culture (Gherardi and Nicolini, 2000, 2002), risk management and labour organisation are clearly very important as well.

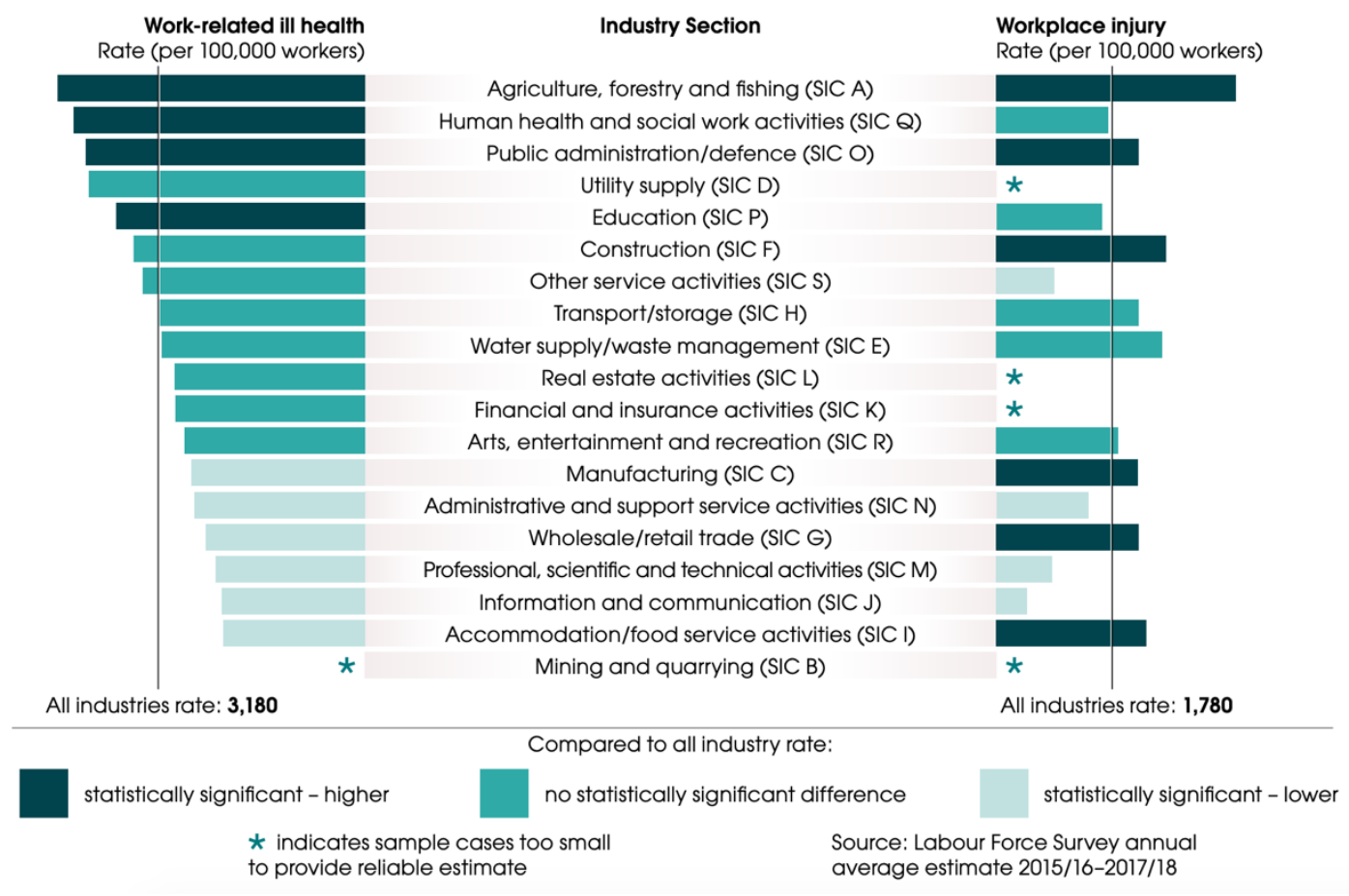

Fig. 2. Rate of self-reported work-related ill health and non-fatal injury by industry. Source: UK HSE, Health and safety at work Summary statistics for Great Britain 2018.

The relatively bad performance of Public Administration as illustrated in Figure 2 could in part be attributable to the police and armed forces being in themselves relatively dangerous jobs, Nevertheless, such linkages between safety and contractual flexibility often display consistency. For example, in Italy, the state is the largest employer of atypical workers thereby going against common assumptions.

It is against this context, mapping the variable performances of European states in OHS issues, that this paper has the following objectives:

1) To review the literature on risk and safety and to analyze the role of organisational climate in affecting safety.

2) To discuss the feasibility of introducing the Capability Approach to Organisation Studies.

\section{Safety, risk, well-being and organisations}

Although in Western Europe the general rate of occupational accidents has decreased during the last 30 years, there seems nevertheless to have been a noteworthy recent increase among atypical workers and foreign workers (Hopkins, 2015; Howes, 2011). This trend of greater risks for non-nationals is also borne out in other European locations. In Austria for example, $37 \%$ of migrant workers surveyed felt affected by poor health conditions at work, compared with only $16 \%$ of Austrian workers. Furthermore, some $30 \%$ of migrant workers felt particularly affected by the risk of accident and injury in their workplace, compared with only $13 \%$ of Austrian nationals. In Spain the statistics build a similar picture: in 20058.4 out of every 100,000 migrant workers died in labour 
accidents, a proportion in excess of that experienced by the Spanish labour force, who were said to have an accident mortality rate of $6.3 \%$ (Eurofound, 2007).

Risk, safety and well-being are complex phenomena that must be tackled at a systemic level, taking into account individual, organisational and institutional factors (Douglas, 1966; Tversky and Kahneman, 1974; Reason, 1990; Giddens, 1991; Beck, 1992; Weick and Sutcliffe, 2001, Weick, 1992; Weick and Roberts, 1993; Perrow, 1994; Gherardi, 2004; Gephart et al., 2009; James and Walters 1997; Guiol and Muñoz, 2009, Muñoz, 2019). Figure 3 illustrates this point, showing how micro level behaviour is affected by a plurality of influences. The authors mentioned above and schematically represented in Figure 4, represent the most important sample of those who have addressed the risk issue academically. A large number of economic and psychological studies on the subject particularly show how individuals calculate risk more or less rationally, both objectively and subjectively. This literature is supplemented by other research findings that stress the way that societies and governments (even in a Marxist perspective) calculate what they deem to be acceptable levels of risk. Additionally, literature within the fields of sociology and ergonomics has done much to emphasise the way technology affects modernity and has done much to illustrate how risk has become an intrinsic characteristic of modern societies.

There is a long tradition of studies on risk and safety among social scientists. In particular, much can be gleaned from the different standpoints and methodologies offered by Organisation Studies, which as a discipline pays much attention to the way perspectives have evolved over decades, simultaneous with broader influential changes in society, technology and economy.

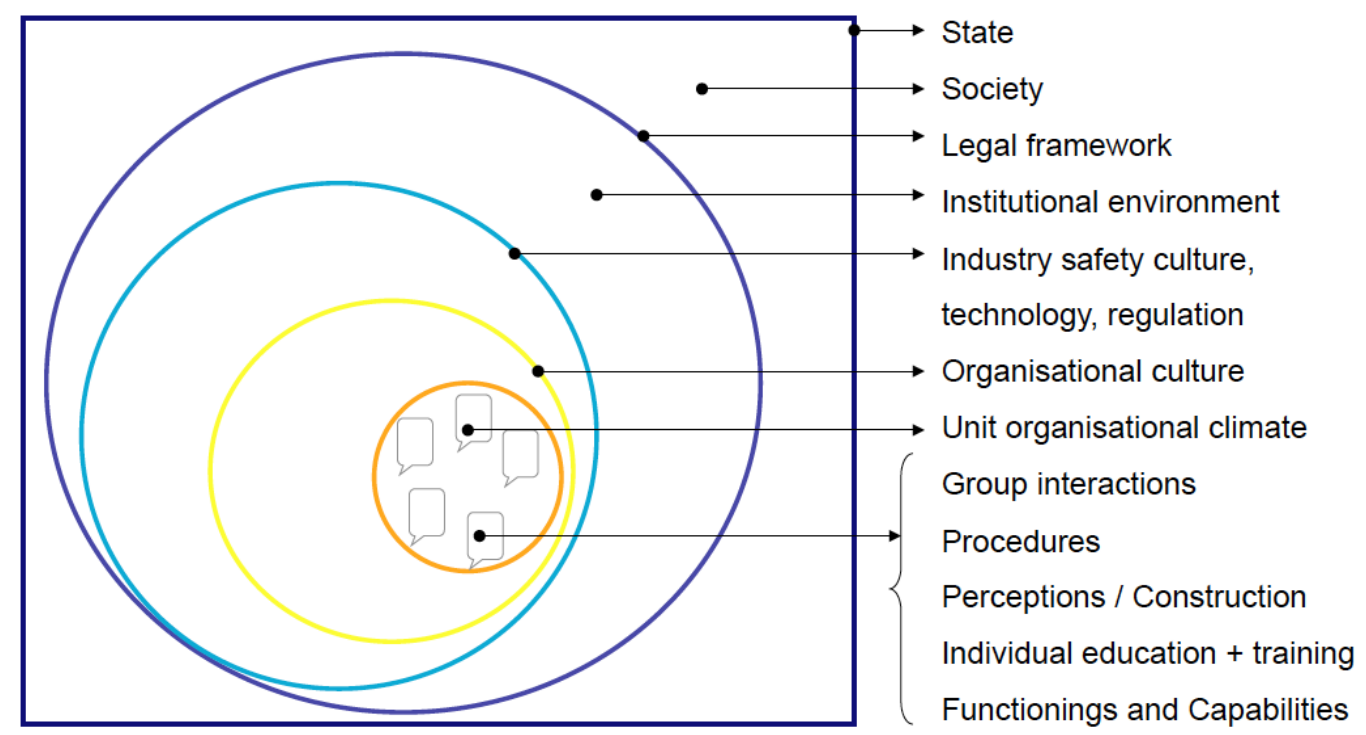

Fig. 3. Levels of risk analysis.

Finally, within Organisation Studies and industrial medicine, research has focussed upon a more detailed and nuanced elucidation of the interrelationship between safety culture, climate or workers' participation both as individual and cumulative factors contributive in helping to lower risk (Scholz \& Vitols, 2019). Organizational climate and organizational culture are very close constructs (see for instance: Denison, 1996; Moran and Volkwein, 1992; Kunda, 1992). A further issue, which has yet not received as much attention, would be to consider the difference between risk and uncertainty at work according to different possible perspectives such as those of Keynes, Knight or Definetti. 
INSIGHTS INTO REGIONAL DEVELOPMENT

ISSN 2669-0195 (online) http://jssidoi.org/jesi/

2019 Volume 1 Number 2 (June)

http://doi.org/10.9770/IRD.2019.1.2(6)

With specific regard to an exploration of the connections between economic democracy (profit sharing, participation, co-operation) and occupational well-being the works of Guiol and Muñoz are particularly interesting. Their studies consider a sample of firms of different business sector and size in France and show that, the organisations with the best record for safety and well-being are those where systems of workers' participation have been most actively implemented (Guiol and Muñoz, 2007, 2009). With regard to the Finnish context, a similar study has been conducted on the relationship between worker's well-being and participation (Bernardi and Köppä, 2011; Scholz \& Vitols, 2019).

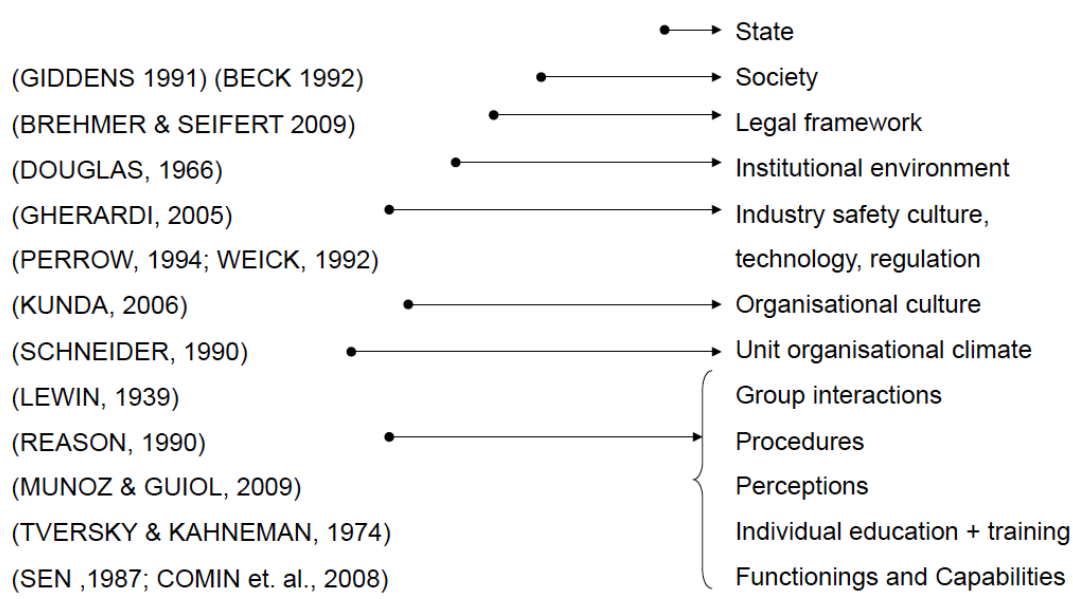

Fig. 4. Levels of risk analysis, literature.

Supplementary to the available literature described above, this paper explores an additional facet - the special aspect of western labour markets concerned with flexibility and atypical contractual arrangements (AmuedoDorantes, 2002, Barrett and Sargeant 2008) in a post Fordism context. It would seem that any discussion of this 'non-standard' segment of the market challenges the suitability of some of the above-discussed model theoretical frameworks (risk society, post-modern society, etc.). Indeed, these frameworks alone cannot explain why in the same industry, and in the same organisation, a worker with a worse contractual status is more likely to be in jeopardy, having either more chance of being affected by occupational diseases, or increased chance of being involved in a fatal accident at work.

I consider that one way of exploring this interrelationship between job insecurity and exposure to risk at work would be to to apply the Human Development and Capability Approach formulated by Sen. This seems particularly pertinent given its intrinsic interest in freedoms and rights and its ability to discern between real and formal abilities and capabilities, taking into account formal and informal institutions (De Muro and Tridico, 2008) and cultural constraints (Alkire, 2002).

"A functioning is an achievement, whereas a capability is the ability to achieve. Functionings are, in a sense, more directly related to living conditions, since they are different aspects of living conditions. Capabilities, in contrast, are notions of freedom, in the positive sense: what real opportunities you have regarding the life you may lead" (Sen, 1987).

We can say that functioning means the act of function, capability instead being the ability plus the real condition and the freedom to use our own ability.

This paper postulates that, together with freedoms, rights and capabilities the role of organisational climate (Woodman and King, 1978; Waters and Roach, 1974; Litwin and Stringer, 1968; Argyris, 1958) and culture (Schein, 2004; Kroeber and Kluckhohn, 1952; Hofstede, 1980) is highly important in affecting individual safety behaviours and performances. Furthermore, the way individuals and groups perceive risk can be variously 


\section{INSIGHTS INTO REGIONAL DEVELOPMENT}

ISSN 2669-0195 (online) http://jssidoi.org/jesi/

2019 Volume 1 Number 2 (June)

http://doi.org/10.9770/IRD.2019.1.2(6)

influenced by organisational climate, by group leaders, by interactions, and by structures and cultures within organisations. As the climate influences the attitudes of workers and managers towards risks and helps to determine the conditions of well-being at work (Lewin et. al., 1939; Schneider, 1990; Kunda, 2006), it seems logical to combine the Capability Approach and the organisational climate as theoretical tools to further examine certain trends and behaviours in the relationship between atypical workers and OHS.

\subsection{Individual behaviour, groups and safety}

Danger is evaluated by individuals not rationally but through filters of perception (Clarke, 1999). The difference between the real (or objective) risk and the perceived (thus subjective) risk is significant because the danger increases if individuals underestimate the real risk. The discrepancy between subjective and objective risk is taken into account in the theory of safety and in the theory of cognitive dissonance. In all cases, the organisational climate plays a role at the individual and group level in identifying and assessing risk.

Organisations can reduce the dissonance by acting on individuals: borrowing neo-institutional terminology, it is possible to influence safety behaviours with normative, cognitive and regulatory actions. The employee - a professional or a manual labourer (white or blue collar) - should be oriented by the organisation and other institutions in its behaviours or attitudes by communicating and explaining what is required to do (regulative), what is appropriate to do (normative), or what is right to do (cognitive). Attempts to change perceptions often encounter strong resistance, since these are the result of processes of self-learning and reinforcement.

The arguments, so far, have highlighted how perceptions influence the subjective cognition of danger and hence individual behaviour. From a systemic perspective it is also necessary to analyze the consequences that the individual perception of risk has on the behaviour of others. In particular, it is important to take into consideration the risk perceptions of executives and entrepreneurs, which are reflected in both the organisational climate and in the labour organisation. Furthermore, the socializing of experiences and perceptions increases both the quality and quantity of group assumptions. Group cohesion makes the socialisation even stronger, amplifying the effects. Safety culture is also built on training risk perceptions and on sharing cognitive elements (Roth et. al., 2006; Payne and Mansfield, 1978).

\subsection{Organisational climate and safety}

Climate analysis and capabilities' development can be considered tools for OHS prevention; initially this paper will consider the importance of climate, taking as axiomatic that organisational culture is the broader environment where climate develops.

There is a large literature on organisational climate (Levin et al., 1939; Schneider, 1975, 1990) and several studies on safety climate in particular (Nasurdin et. al., 2006; Johnstone and Johnston, 2005; Vaananen et al., 2004; Neal et. al., 2000; Miceli and Near, 1985; Zohar, 1980). There are no major studies, however, on the relationship between safety, climate (in a broad, general, sense) and organisational well-being. In this section I will try to explain how the general climate and well-being can influence safety conditions and the level of objective risk.

The reality is a complicated one. Climatic elements can even promote, for instance, a no-blame approach (most easily exemplified via the airline industry). Some organisational cultures, in contrast (for example those developed around productivity stress or cocky and macho behaviours) may instead encourage the spread of assumptions without explicit managerial direction, which is particularly dangerous when linked to safety.

A useful means of highlighting the power of these different organisational climates would be to consider policies towards whistle blowing, beyond the protection provided by the law for workers reporting illegal offences. In this context, it is important that internal mechanisms should permit employees to communicate sensitive information to top management or authorities in confidence. Organisations need to develop policies and tools to facilitate 


\section{INSIGHTS INTO REGIONAL DEVELOPMENT}

ISSN 2669-0195 (online) http://jssidoi.org/jesi/

2019 Volume 1 Number 2 (June)

http://doi.org/10.9770/IRD.2019.1.2(6)

whistle blowing, and above all, they have to foster a climate that encourages those behaviours and identifies them as safe and morally right. Judicial protection alone may not provide sufficient incentive.

The relationship between climate and safety therefore seems sensible, even self-evidential, and has already been studied in the literature. An organisation's success or failure can thus depend on its organisational climate. What is not explained, however, is how job insecurity varies amongst different categories of worker. How is it possible that a given job in a given factory is statistically more dangerous for non standard and alien workers than for their so-called 'standard' counterparts? Some possible reasons readily present themselves (the dynamics of the underground economy, the propensity to assign harder tasks for weaker workers, and so on), but this phenomenon still lacks scientific analysis.

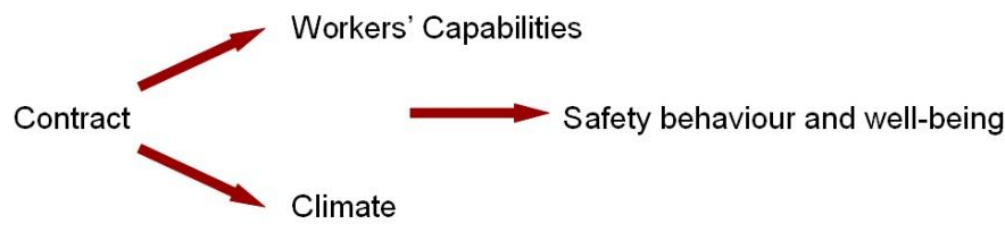

Fig. 5. Contractual arrangement, climate, capabilities, behaviour.

Figure 5 explains how the contractual arrangement influences behaviour and, in turn, safety performance: naturally contractual arrangements confer different status within organisational climate. The organisational climate is a mediator between individuals and the collective cognitive phenomena. It can amplify or limit the individual perceptions of risk. The climate can allow colleagues with full contractual rights to ask their atypical co-workers to be allocated the most risky, unsafe, unpleasant or stressful tasks. The climate can help the individual to define subjective risk and it can influence the group appraisal of objective risk.

To further elucidate this analysis the Capability Approach can be usefully used. Given that the phenomenon described in this paper is one mainly based on differential access to rights, since an employment contract is mostly an issue of rights and duties, it is my contention that the Capability Approach can supply a useful tool to dissect and understand the complex interrelationship between rights, well-being and safety.

\section{The Capability Approach and organisations}

The Capability Approach (CA) was introduced by Amartya Sen in 1988, ten years before he received the Nobel Prize. Since then, the approach has been widely used among scholars of many disciplines, but mainly amongst those studying national or regional level phenomena. The main idea of this school stresses the need for both researchers and policymakers to look at capabilities, rather than merely consider economic data or formal legal systems (Fukuda-Parr, 2003; Sen, 1994). Equality and development should be pursued, Sen has argued, through capabilities that encapsulate notions of freedom and real opportunities regarding the desired life.

Capabilities as defined by Sen are enabled by rights and functionings (in our case education, safety, health, and so on). The well-being of citizens and the development of nations rely on capabilities and real equality of opportunity and not on GDP per capita, which has sometimes been the principal measure of assets, or equality of resources, or primary goods as suggested by Dwarkin (2000) or Rawls (1972).

Currently, the Capability Approach is used by researchers with different educational backgrounds involving many fields of study, including economics, anthropology, philosophy, political science, psychology, education science, health studies, welfare and public policy. There are also studies on labour, welfare and happiness, with a micro - 
INSIGHTS INTO REGIONAL DEVELOPMENT

ISSN 2669-0195 (online) http://jssidoi.org/jesi/

2019 Volume 1 Number 2 (June)

http://doi.org/10.9770/IRD.2019.1.2(6)

or macro - economic emphasis. There have been no applications to Organisational Studies, however. Traditional applications, (such as is illustrated in Figure 6) have seen policy makers and researchers concentrating upon human development indicators, rather than on growth or economic development.

In a liberal and pluralistic view of individual ambitions and well-being, scholars utilising the CA believe that the state should grant citizens freedoms and opportunities to achieve certain essential 'rights' or functionings (health, education, safety, for instance). Given a personal set of functionings, human beings should then be able to pursue their own selected goals for well-being, thanks to their own capabilities. A given set of functionings can be defined as the creation of an environment that allows positive pluralistic opportunities for citizens to both be and behave, it provides a context in which there is freedom and there is real (not merely formal) equality of opportunity. Furthermore, once citizens are placed in such an environment, they are given the possibility to acquire some capabilities and to use them autonomously in their own lives. Participation could well be considered as a functioning referring to workers' participation as well as the more traditional interpretation focussing on political participation.

A study of human development differs from other examinations of liberal frameworks of equality (see for instance those examined by Rawls or Dwarkin) because it does not focus on equality in terms of the rule of law or on access to primary goods or resources. Human development instead concentrates on the equal ability of citizens to pursue well-being in the context of all the cultural or social constraints on human development. It is worth noting that researchers of this school frequently also focus on economic development, but they believe that economic development is a consequence of human development, not its cause.

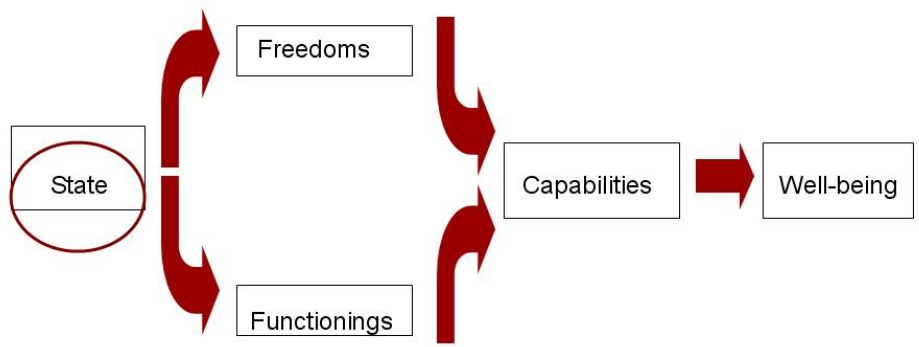

Fig. 6. Capability Approach and Human Development, at a regional level.

So far, the areas where the Capability Approach has been mostly developed are: the analysis of human development at national or regional level (Sen, 1985a; Comin et al., 2008); the analysis of well-being and local development (Alkire, 2002); the study of the conditions of the poor in developing countries; the development itself (Klasen, 2000; Qizilbash, 2002); the measurement of poverty and welfare in advanced economies; the study of the difficulties of disabled people; the study of gender discriminations (Sen 1985b; Robeyns 2003; Monni and Costantini, 2008; Nussbaum, 2000) and the analysis of public policies (Schokkaert and Van Ootegem, 1990).

To the extent that Organisational Studies deals with the individual and collective welfare of workers, the development of their potential contribution, the understanding of the exchange of contributions and incentives, cultural diversity, the psychological components of organisational behaviour, and with fairness, justice and change, the Capability Approach seems to offer an original opportunity for researchers. Perhaps surprisingly however, although this framework has been widely used, it has not been applied within Organisational Studies. Yet, its usefulness is immediately apparent. Rather than consider OHS, matters such as formal obligations, legal formalities or the presence of safety tools (hard hats and extinguishers for instance), it is perhaps more useful instead to focus on capabilities (the real abilities of workers to protect themselves) and on their freedom to request safe environments and proper procedures. This represents the measure of the potency of workers to affect or assume change within their working environments. Understanding the capabilities of atypical workers in this way, 
by locating them within their various organisational climates, therefore provides a tangible means of understanding how contractual insecurity turns into risk and helps explain why foreign workers are in greater danger where they lack education, language skills and rights.

The Capability Approach can be combined together with analysis of organisational climate to provide insights into OHS trends at the organisational level. Shifting from the regional to the organisational level, the most important institution is no longer the state, but the organisation itself, given the importance and the role of all the other institutions (ILO, 2004), both formal and informal (Drury, 1983; Collinson, 1999).

Figure 7 illustrates the methodological framework with reference to OHS and one specific capability which I call Safety Capability and which I define as: the worker's attitude to self protection through the understanding of safety procedures, the proper assessment of the objective risk and the freedom to ask the organisation to respect the law and to implement safe work processes" fitting the environmental and technological context.

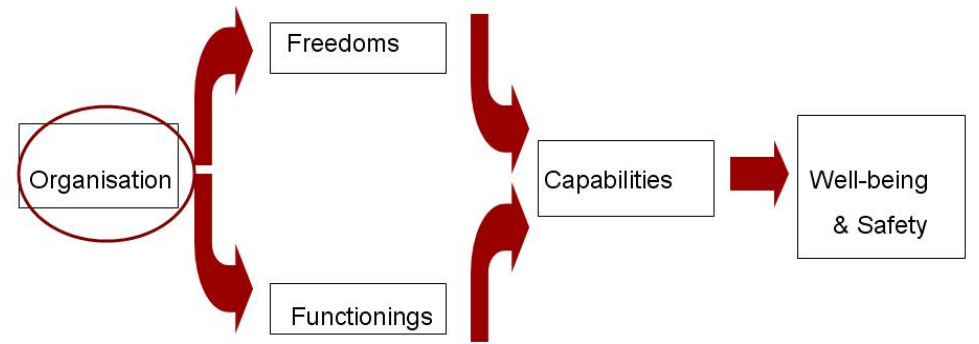

Fig. 7. Capability Approach and Organisational Development at the organizational level.

Some studies (Bernardi 2009, 2010) have been conducted with this methodology. The empirical findings were interesting. In the workplace it seems that workers' capabilities are activated by particular functionings, namely autonomy, trade union rights, occupational well-being, organizational equity, labour rights and workers' safety awareness (Keune \& Pedaci, 2019). As in Sen's original application, functionings need a general context of freedom in order to flourish.

To assess workers' Human Development (meaning the development of their functioning and capabilities), however, one needs to place them in the context of Organisational Development. This re-orientation recognises the importance of Organisational Development as the primary means of fostering both individual and collective well-being at work. Human Development in contrast, tends to be a more useful lens via which to analyse the economic and social development of a nation or region.

\section{Capability Approach and safety}

Sen introduces the idea that the satiation of basic needs is a means to ensure positive rights or to improve the ability of individuals to exercise their rights of freedom in different areas, ranging from the social to the political and economic. Sen tries to analyze and measure these individual achievements and values by focusing his research on what people are theoretically able (or, to use his term, capable) to do because of the context in which they exist, rather than focusing on the tangible economic opportunities offered to them through disposable income, consumption or spending. This analytical framework therefore measures not only earnings, property, and 


\section{INSIGHTS INTO REGIONAL DEVELOPMENT}

ISSN 2669-0195 (online) http://jssidoi.org/jesi/

2019 Volume 1 Number 2 (June)

http://doi.org/10.9770/IRD.2019.1.2(6)

consumption but individual self-esteem, the way an individual is regarded by the community and their well-being in the workplace (for the purposes of this paper organisational climate and OHS). In short, this model gives more emphasis to the well-being of individuals and to their satisfaction of feeling fully realized as human beings. These intangible conditions are harder to measure than national product, per capita income, or a nation's endowment of infrastructure. According to Sen, the capabilities of individuals to achieve what they aspire to match with freedom: the freedom to do what you want in a context of "equality of opportunities".

The capabilities' framework is based on two concepts: freedom and valuable beings and doings. Sen managed to summarize both terms into a single expression, functionings. This encapsulates what every person is able to obtain and to achieve during his lifetime, in Sen's terminology their "doings" and "beings". But how can we achieve these states of being? At this point, Sen develops a path based on individual capabilities. According to him, the capabilities of a person depend on a variety of factors, including personal and social assets (i.e. what the social conditions of individuals are and how society handles it). Every person, according to Sen, has a set of basic and general capabilities, which is one of the several possible combinations of functionings that he is able to achieve. The basic capabilities refer to the freedom to do whatever is necessary to escape from a state of poverty. This model has become crucial for the analysis of poverty, and more generally, to analyze well-being (quality of life) (for example, Nussbaum and Sen, 1993). "General capabilities" are described as growing in a pleasant and healthy environment and refer to physical and mental health, education and knowledge, social relations and interactions, physical and moral well-being (Sen, 1983). The basic idea is that the abilities of individuals are linked to their actual freedom to be whatever they want and to achieve what they aspire to: that is "what are the real opportunities you have to live as you want" (Sen, 1987). Freedoms are closely related to functionings which are what you absolutely need to carry out your own capabilities (Figure 7).

In this view, the Capability Approach can be used with regard to the development of individuals that are part of an organisation (see Figure 7). In particular, we look at the conditions that an organisation can provide to foster Safety Capability as defined above. Organisational freedoms refer to trade union rights, the respect of employment rights, and freedom of association among workers. These freedoms underpin the functionings, relating to health and safety that have already been identified earlier in this paper: general organisational climate, safety compliance attitudes, well-being at workplace, autonomy, participation, proper training, equity and the general respect of rules.

It is my contention, based on the existing and above mentioned literature on health, safety and risk at work, that this combination of functionings is the root of Safety Capability: namely a complex tacit knowledge acquired by the worker that allows him to understand the importance of safety standards, to demand respect for rules, to limit the divergence between objective and subjective risk evaluation, and independently, if necessary, to take own measures to ensure his individual, group and organisational safety.

\subsection{Possible Applications}

This paper aims to put forward a new tool for OHS analysis. To do so, I have proposed a new means of measurement, one that takes into account both the climate of organisational units and the capabilities of workers. The capabilities framework enables us to understand that human beings are fully able to exercise their rights, to express their personality, to achieve personal satisfaction only if they can rely on an endowment of skills, suitable physical and moral conditions (Herzberg, 1959), or knowledge. It is ineffective to know your rights if you are not able to make a full use of them. To give an example at national level, Sen would argue that nothing is achieved by allowing under-privileged black citizens in the USA formal political rights unless they feel enabled and motivated to vote. Similarly, the presence of a university in a town is of no value to women if the local culture prevents them from studying there. In the same way, the full benefit of having purchasing power is undermined by poor education if this leads to the consumption of junk food and a consequently lower life expectancy. 


\section{INSIGHTS INTO REGIONAL DEVELOPMENT}

ISSN 2669-0195 (online) http://jssidoi.org/jesi/

2019 Volume 1 Number 2 (June)

http://doi.org/10.9770/IRD.2019.1.2(6)

Following this line of argument, it is not enough for a worker to simply be aware of a safe procedure, especially if he is part of an organisation that fosters risky behaviours, either formally or informally. Awareness of risk may not lead to the adoption of safe procedures in the face of a challenging climate and the negative attitudes of colleagues, managers (Greasley \& Edwards, 2015) or groups. A positive circumstance would be one where the employee should enjoy a condition of freedom and well-being. In this context, organisational well-being is a necessary condition in order for the worker to be able to protect himself from risks. Freedom, which generally speaking suggests a condition of equity and the respect of rules, creates a situation whereby workers feel at liberty to call for safe tasks and procedures. Freedom is also the ability to make full use of a proper level of autonomy where the procedures are objectively hazardous or where it is necessary to intervene in order to avoid an accident. Finally, freedom implies that a worker may denounce violations of rules and proper procedure and illegal conditions without having to fear serious personal consequences.

Within a context of well-being, in a lawful environment where there is respect for safety rules, it is possible to reduce the cognitive dissonance between subjective and objective risks. Organisations should promote awareness and risk assessments that are reasonably objective (Neal et. al., 2000). On the other hand, some organisational cultures may instead promote risky assumptions concerning processes, rules, procedures and safety related behaviours.

Short term and atypical workers, foreign citizens or illegal workers usually have little freedom, social security, education, psychological confidence, autonomy or bargaining power. That is why such workers have to fight against false assumptions, if they are to refuse to undertake excessively dangerous tasks or challenge the perception of risk within the organisational unit: factory, office, shop, small firm or complex organisation. Furthermore, the social interactions and organisational behaviour of employees, who are not fully free, either in terms of employment contract, or in terms of evaluating skills, entail risk. The social construction of reality (Berger and Luckmann, 1966) among citizens who are not free or workers who are not skilled is risky.

Education, safety awareness, participation and the active use of civil and trade union rights give to any employee the capacity to take advantage of the available opportunities (Keune \& Pedaci, 2019). It is the comparative lack of access to these that creates a situation of greater risk among foreign workers and non-standard workers. Further empirical studies could usefully study the relationship between safety attitudes (a capability), the organisational climate and the labour employment status (intended and measured both as functionings). Respondents would manifest their level of agreement with propositions on a Likert Scale. Socio demographic information and health confidential data, anonymously coupled with each questionnaire, could be collected. The functionings could be measured from the questionnaire and from data on health conditions and safety history obtained from the employer and from national authorities.

The hypothesis that the Safety Capability of workers (dependent variable) depends on functionings (predictors, independent variables) could then be tested using a linear regression. At that point it would be possible to say whether the safety climate, the quality of work, the general respect for rules, and the job stability and other possible factors are useful indicators to ensure that safety standards are understood and respected by workers with a proper attitude towards risk. Such a theoretical construct can also be seen in the form of a linear regression equation that relates the dependent variable capability to the functionings that are independent variables.

\section{Conclusions}

Going back to the original research question posed in this paper, my purpose was to demonstrate that in OHS the overall organisational climate influences safety behaviours. Organisational Studies can be very useful in dealing with safety at work, not least as it is clear that labour organisation and safety climate do matter; as evidenced in 


\section{INSIGHTS INTO REGIONAL DEVELOPMENT}

ISSN 2669-0195 (online) http://jssidoi.org/jesi/

2019 Volume 1 Number 2 (June)

http://doi.org/10.9770/IRD.2019.1.2(6)

Figure 3. Using a complex definition of safety prevention skills and a broader definition of well-being, it is clear that not only the safety climate but the entire general climate within an organisation influences OHS related behaviours. Moreover, the aim of this piece was to introduce the Capability Approach to Organisational Studies researchers. In my view, this study has revealed no incompatibilities between this approach and the general theoretical framework of Organisational Studies. Indeed, it is hoped that this work will show how Amartya Sen's framework can be applied in the field of Organisational Studies by addressing not only issues of well-being and safety but also by using it throughout the array of existing research interests and methodologies. Finally, by combining these two approaches, this paper should be seen as contributing to debates on economic democracy, not least with regard to the relationship that can be clearly mapped between workers' rights and participation and their occupational health.

The recession following the 2008 financial crisis triggered major reforms of labour market regulation in Europe, it also rebrought major changes to employees' experiences at work (Ogbonnaya, Gahan \& Eib, 2019). It is now time to investigate if those recessionary changes at work had any impact on the health and safety of workers across Europe. This approach could contribute to such a study.

\section{References}

Alkire, S. 2002. Valuing Freedoms: Sen's Capability Approach and Poverty Reduction, Oxford University Press, Oxford.

Amuedo-Dorantes, C. 2002. Work Safety in the Context of Temporary Employment: The Spanish Experience, Industrial and Labor Relations Review https://doi.org/10.1177/001979390205500204

Argyris, C. 1958. Some problems in conceptualizing organizational climate: a case study of a bank, Administrative Science Quarterly, 501520.

Barrett, B., Sargeant, M. 2008. Health and Safety Issues in New Forms of Employment and Work Organization, International Journal of Comparative Labour Law and Industrial Relations, n24, pp. 243-261.

Beck, U. 1992. Risk society: Towards a new modernity, Thousand Oaks, CA: Sage.

Berger, P.L., Luckmann, T. 1966. The social construction of reality, Doubleday and Co., Garden City, New York.

Bernardi, A. 2009. Job safety and well-being in organizations. Climate, capabilities and functionings as tools for analysis and prevention, doctoral dissertation in Italian, University of Milan, Bicocca.

Bernardi, A. 2010. Studying occupational health and safety using the Capability Approach at organisational level, proceedings of "Health and Safety and Vulnerable Workers in a Changing World of Work", June 2010, London Middlesex University.

Bernardi, A., Köppä T. 2011. Co-operatives as better working places. The Finnish case in a comparative organisational climate analysis, The international Journal of Co-operative Management, special issue on Finland.

Clarke, S. 1999. Perceptions of Organizational Safety: Implications for the Development of Safety Culture, Journal of Organizational Behavior 20(2) https://doi.org/10.1002/(SICI)1099-1379(199903)20:2<185::AID-JOB892>3.0.CO;2-C

Collinson, D.L. 1999. 'Surviving the Rigs': Safety and Surveillance on North Sea Oil Installations, Organization Studies. https://doi.org/10.1177/0170840699204003

Comim F., Qizilbash, M., Alkire, S. 2008. (Eds) The Capability Approach, Cambridge University Press, Cambridge.

Costantini V., Monni S. 2008. Environment, Human Development and Economic Growth, Ecological Economics, 64, 4, pp.867-880. https://doi.org/10.1016/j.ecolecon.2007.05.011 
INSIGHTS INTO REGIONAL DEVELOPMENT

ISSN 2669-0195 (online) http://jssidoi.org/jesi/

2019 Volume 1 Number 2 (June)

http://doi.org/10.9770/IRD.2019.1.2(6)

De Muro P., Tridico, P. 2008. The role of institutions for human development, XX EAEPE Conference, Roma Tre University.

Denison, D.R. 1996. What is the difference between organizational culture and organizational climate? A native's point of view on a decade of paradigm wars, The Academy of Management Review, 21(3), pp. 619-654. https://doi.org/10.2307/258997

Douglas, M. 1966. Purity and danger, London, Ark Paperbacks.

Drury, G. C. 1983. Task analysis methods in industry, Applied Ergonomics, 14, pp. 19-28.

Dwarkin, R. 2000. Sovereign Virtue: The Theory and Practice of Equality, Harvard University Press.

Eurofound. 2007. Employment and working conditions of migrant workers, Dublin.

Fukuda-Parr, S. 2003. The human development paradigm: operationalizing Sen's ideas on capabilities, Feminist Economics, 9(2/3), 301317 https://doi.org/10.1080/1354570022000077980

Gephart, R. P. Jr, Van Maanen, J., Oberlechner, T. 2009. Organizations and Risk in Late Modernity, Organization Studies, 30 issue $02 \& 03$ https://doi.org/10.1177/0170840605056909

Gherardi, S. 2004. Translating Knowledge While Mending Organizational Safety Culture, Risk Management: an International Journal, 6, 2, pp. 61-80. https://www.jstor.org/stable/3867697

Gherardi, S., Nicolini, D. 2000. To Transfer is to Transform: The Circulation of Safety Knowledge, Organization. https://doi.org/10.1177/135050840072008

Gherardi, S., Nicolini, D. 2002. Learning the Trade: A Culture of Safety in Practice, Organization. https://doi.org/10.1177/1350508402009002264

Giddens, A. 1991. Modernity and self-identity, Cambridge, Press. $\underline{\text { https://biblio.csusm.edu/sites/default/files/reserves/giddens_modernity_and_self-identity_ocr.pdf }}$

Greasley, K., \& Edwards, P. 2015. When do health and well-being interventions work? Managerial commitment and context. Economic and Industrial Democracy, 36(2), 355-377. http://doi.org/10.1177/0143831X13508590

Guiol P., Muñoz J. 2007. Management, participation et santé des salariés: des médecins et des salariés parlent, RECMA, n 304, p. 76-96.

Guiol P., Muñoz J. 2009. Management des entreprises et santé des salariés, Presse Universitaires de Rennes, Rennes.

Herzberg, F. 1959. The Motivation to Work, John Wiley and Sons, New York.

Hofstede, G.H. 1980. Culture's Consequences - International Differences in Work-Related Values, Sage Publications, London.

Hopkins, B. 2015. Occupational health and safety of temporary and agency workers, Economic and Industrial Democracy https://doi.org/10.1177/0143831X15581424

Howes V. 2011. Who is Responsible for Health and Safety of Temporary Workers? EU and UK Perspectives Victoria, European Labour Law Journal https://doi.org/10.1177/201395251100200405

ILO. 2004. A promotional framework for occupational safety and health, Report 93 IV (1), Geneva. https://www.ilo.org/public/english/standards/relm/ilc/ilc93/pdf/rep-iv-1.pdf

James P., Walters, D. 1997. Non-union rights of involvement: the case of health and safety at work, Industrial Law Journal 26(1), 33-48, January, ISSN 0305-9332.

Johnstone, A., Johnston, L. 2005. The relationship between organizational climate, occupational type and workhaolism, New Zealand Journal of Psychology, 34(3), 181- 188.

Keune, M., \& Pedaci, M. 2019. Trade union strategies against precarious work: Common trends and sectoral divergence in the EU, European Journal of Industrial Relations http://doi.org/10.1177/0959680119827182 
INSIGHTS INTO REGIONAL DEVELOPMENT

ISSN 2669-0195 (online) http://jssidoi.org/jesi/

2019 Volume 1 Number 2 (June)

http://doi.org/10.9770/IRD.2019.1.2(6)

Klasen, S. 2000. Measuring Poverty and Deprivation in South Africa, Review of Income and Wealth 46: 33-58. https://doi.org/10.1111/j.1475-4991.2000.tb00390.x

Kleinknecht, A. 2008. The impact of labour market deregulation on jobs and productivity: Empirical evidence and a non-orthodox view, EAEPE Annual Conference, University of Roma Tre, 6-8 November, Rome.

Kok, W. 2004. Facing the challenge. The Lisbon Strategy for Employment and Growth, Report from the High-Level Group, chaired by Wim Kok, Office for Official Publications of the European Communities, Luxembourg.

Kroeber, A., Kluckhohn, C. 1952. Culture, Meridian Books, New York.

Kunda, G. 1992. Engineering Culture. Control and Commitment in a High-Tech Corporation, Philadelphia, Temple University Press.

Kunda, G., Barley, S.R. 2006. Gurus, Hired Guns, and Warm Bodies: Itinerant Experts in a Knowledge Economy, Princeton University Press, Princeton.

Lewin, K., Lippitt, R., White, R. 1939. Patterns of Aggressive Behavior in Experimentally Created Social Climates, Journal of Social Psychology, 10, 271-299. http://dx.doi.org/10.1080/00224545.1939.9713366

Litwin, G., Stringer, R., 1968, Motivation and organizational climate, Harvard University Press, Cambridge, MA.

Miceli M.P., Near J.P. 1985. Characteristics of organizational climate and perceived wrongdoing associated with whistle-blowing decisions, Personnel Psychology 38, 525-544. https://doi.org/10.1111/j.1744-6570.1985.tb00558.x

Moran, E.T., Volkwein, J.F. 1992. The cultural approach to the formation of organizational climate, Human Relations, 45(1), 19-47. http://dx.doi.org/10.1177/001872679204500102

Muñoz, J. 2019. Benessere, in A. Bernardi, S. Monni, a cura di, (2019) Parole Chiave per l'Impresa Cooperativa del Futuro, Il Mulino, Bologna.

Nasurdin, A.M., Ramayah, T., Beng, Y.C. 2006. Organizational structure and organizational climate as predictors of job stress: evidence from Malaysia, International Journal of Commerce and Management, 16(2), 116-129.

Neal, A., Griffin, M.A., Hart, P.M. 2000. The impact of organizational climate on safety climate and individual behaviour, Safety Science, 34, 99-109.

Nussbaum M. C., Sen, A. (Eds) 1993. The quality of life, Helsinki United Nation University, WIDER, Helsinki.

Nussbaum, M.C. 2000. Women and Human Development: The Capabilities Approach, Cambridge University Press, Cambridge.

Ogbonnaya, C., Gahan, P., \& Eib, C. 2019. Recessionary changes at work and employee well-being: The protective roles of national and workplace institutions, European Journal of Industrial Relations http://doi.org/10.1177/0959680119830885

Payne R., Mansfield R. 1978. Correlates of individual perceptions of organizational climate, Journal of Occupational Psychology, 51, 209218. https://doi.org/10.1111/j.2044-8325.1978.tb00417.x

Perrow, C. 1994. Accidents in high risk systems, Technology Studies 1/1: 1-20.

Qizilbash, M. 2002. A note on the measurement of poverty and vulnerability in the South African context, Journal of International Development, (14), pp.757-772. https://doi.org/10.1002/jid.922

Rawls, J. 1972. A Theory of Justice, Oxford University Press, Oxford.

Reason, J. 1990. Human Error, Cambridge University Press, Cambridge.

Robeyns, I. 2003. Sen's Capability Approach and Gender Inequality: Selecting relevant capabilities, Feminist Economics, 9(2-3), pp. 61-92, July-November. https://doi.org/10.1080/1354570022000078024

Robeyns, I. 2005. The capability approach: a theoretical survey, Journal of Human Development 6(1), 93-114. 
INSIGHTS INTO REGIONAL DEVELOPMENT

ISSN 2669-0195 (online) http://jssidoi.org/jesi/

2019 Volume 1 Number 2 (June)

http://doi.org/10.9770/IRD.2019.1.2(6)

https://doi.org/10.1080/146498805200034266

Roth, E.M., Multer, J., Raslear, T. 2006. Shared Situation Awareness as a Contributor to High Reliability Performance in Railroad Operations, Organization Studies https://doi.org/10.1177/0170840606065705

Schein, E. 2004. Organizational Culture and Leadership, Wiley Publishers, New York.

Schneider, B. 1975. Organizational climate: an essay, Personnel Psychology 28, 447-479.

Schneider, B. 1990. Organizational Climate and Culture, Jossey-Bass, San Francisco.

Schokkaert, E., Van Ootegem, L. 1990. Sen's Concept of the Living Standard applied to the Belgian Unemployed, Recherches Economiques de Louvain, 56(1990)3-4, pp. 429-450.

Sen, A.K. 1983. Development: Which Way Now?, The Economic Journal 93, pp. 745-62.

Sen, A.K. 1985a. A Sociological approach to the measurement of Poverty: a reply to prof. Peter Townsend, Oxford Economic, Papers n.37.

Sen, A.K. 1985b. Commodities and Capabilities, North Holland, Amsterdam.

Sen, A.K. 1987. The Standard of Living, Cambridge University Press, Cambridge.

Sen, A.K. 1994. Growth economics: what and why? In: Pasinetti, L., Solow, R.M. (Eds.), Economic Growth and the Structure of LongTerm Development, Macmillan, London.

Scholz, R., \& Vitols, S. 2019. Board-level codetermination: A driving force for corporate social responsibility in German companies? European Journal of Industrial Relations http://doi.org/10.1177/0959680119830566

Tversky, A., Kahneman, D. 1974. Judgement under uncertainty: Heuristics and biases: biases in judgments reveal some heuristics of thinking under uncertainty, Science 185: 1124-1131.

Vaananen A., Kalimo R., Toppinen-Tanner S., Mutanen P., Peiro J.M., Kivimaki M., Vahtera J. 2004. Role clarity, fairness, and organizational climate as predictors of sickness absence, Scandinavian Journal of Public Health, 32, 426-424.

Waters, L.K., Batlis, N., Roach, D. 1974. Organizational climate dimensions and job-related attitudes, Personnel Psychology 27, 465-476. http://dx.doi.org/10.1111/j.1744-6570.1974.tb01168.x

Weick, K.E., Sutcliffe, K. 2001. Managing the unexpected, Jossey-Bass, San Francisco.

Weick, K. E. 1992. The collapse of sense making in organizations: The Mann Gulch disaster, Administrative Science Quarterly 38/4: 628652 .

Weick, K.E., Roberts, K. 1993. Collective Mind in organizations: heedful interrelating on flight decks, Administrative Science Quarterly, Sept. 38(3) http://doi.org/10.2307/2393372

Woodman, R.W., King, D.C. 1978. Organizational climate: science or folklore?, The Academy of Management Review, 3(4), 816-826. 10.5465/AMR.1978.4289290

Zohar, D. 1980. Safety climate in industrial organizations: theoretical and applied implications, Journal of Applied Psychology, n. 12. http://doi.org/10.1037/0021-9010.65.1.96 
INSIGHTS INTO REGIONAL DEVELOPMENT

ISSN 2669-0195 (online) http://jssidoi.org/jesi/

2019 Volume 1 Number 2 (June)

http://doi.org/10.9770/IRD.2019.1.2(6)

\section{Aknowledgements}

Parts of this text are spinoffs from research in the framework of the project European Union's Horizon 2020 Research and Innovation Programme projects European Cohort Development Project (ECDP) Grant Agreement No.777449 (2018-2019)

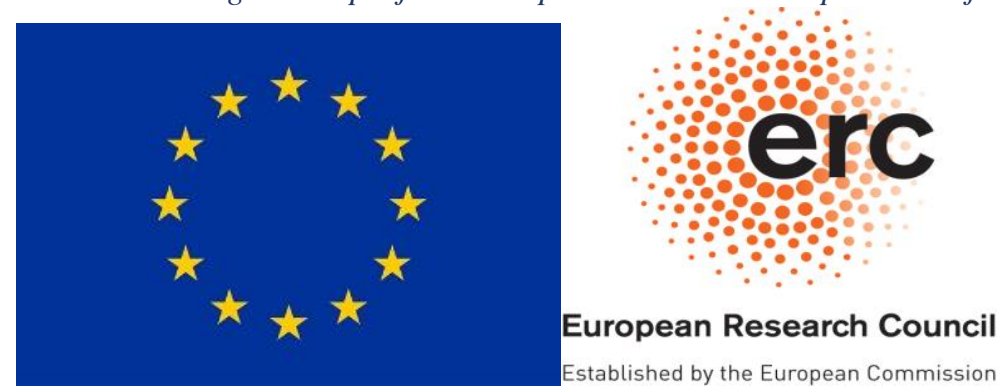

Andrea BERNARDI is the Senior Lecturer in Employment and Organization Studies at Oxford Brookes University in the United Kingdom. He holds a doctorate in Organization Theory from the University of Milan (Bicocca). After studying in Rome, Copenhagen and Milan, he started his academic career in Italy before moving to the University of Helsinki and then the University of Nottingham, China. I then worked for four years at Manchester Metropolitan University before arriving at Oxford Brookes in 2016. His main research contributions relate to the co-operative sector, including Chinese co-operatives. He also works on employment relations and inequality and he has further interests in the study of time, the past, and history in management and organizational studies. His research has maintained three consistent characteristics across my career to date: its collaborative genesis, its openness to the benefits and challenges of interdisciplinarity, and its concern with approaching its objects of study using the insights and methods of history.

ORCID ID: https://orcid.org/0000-0003-2571-6817

Copyright (C) 2019 by author(s) and VsI Entrepreneurship and Sustainability Center

This work is licensed under the Creative Commons Attribution International License (CC BY).

http://creativecommons.org/licenses/by/4.0/

c) (i) Open Access 